\title{
Shale inhibition by low-molecular-weight cationic polymer in water- based mud
}

\author{
Mukarram Beg $^{1} \cdot$ Priyanka Singh $^{1} \cdot$ Shivanjali Sharma ${ }^{1}\left[\right.$. Umaprasana Ojha ${ }^{2}$
}

Received: 27 July 2018 / Accepted: 23 November 2018 / Published online: 29 November 2018

(c) The Author(s) 2018

\begin{abstract}
The presence of oligomers possessing amine or ammonium functionality in drilling fluid plays an important role in stabilizing the shale formations during drilling with water-based mud. In this study, we have compared the activity of neutral to charged amine polymers towards shale stabilization. Low-molecular-weight polymer possessing charged moieties provided superior inhibitive capacity compared to that of the neutral amine functionality-based polymer. The polymer with cationic functionality (polyAETMAC) exhibited higher shale recovery, lesser shale swelling and lower capillary suction time compared to that of the neutral amine-based system (polyDMAPMA) supporting the above. Shale recovery in shale disintegration test improved from 92.3 to $98.7 \%$ for polyAETMAC concentration of $0.625 \mathrm{w} / \mathrm{v} \%$ in water-based mud. The prodigious shale recovery is attributed to the strong interaction between the cationic sites of the polymer with the minerals present in the shale. The overall rheological properties of drilling fluids also improved in the presence of charged amine polymer before and after hot rolling. Apparent viscosity of mud increased by $\sim 29 \%$ for polyAETMAC as compared to $\sim 25 \%$ for polyDMAPMA at a concentration of $0.625 \mathrm{w} / \mathrm{v} \%$. Plastic viscosity and yield point of base mud were also improved by $\sim 43 \%$ and $\sim 15 \%$ at $0.0625 \mathrm{w} / \mathrm{v} \%$ concentration of polyAETMAC and to a similar extent by polyDMAPMA for the same concentration. The decrease in API fluid loss after hot rolling of drilling fluid at $100{ }^{\circ} \mathrm{C}$ for $16 \mathrm{~h}$ was $\sim 20 \%$ for polyDMAPMA and $\sim 13 \%$ for polyAETMAC compared to base mud for the same concentration of the polymers. These polymers can be used as a potential shale stabilizer for water-based drilling fluids.
\end{abstract}

\section{Graphical abstract}

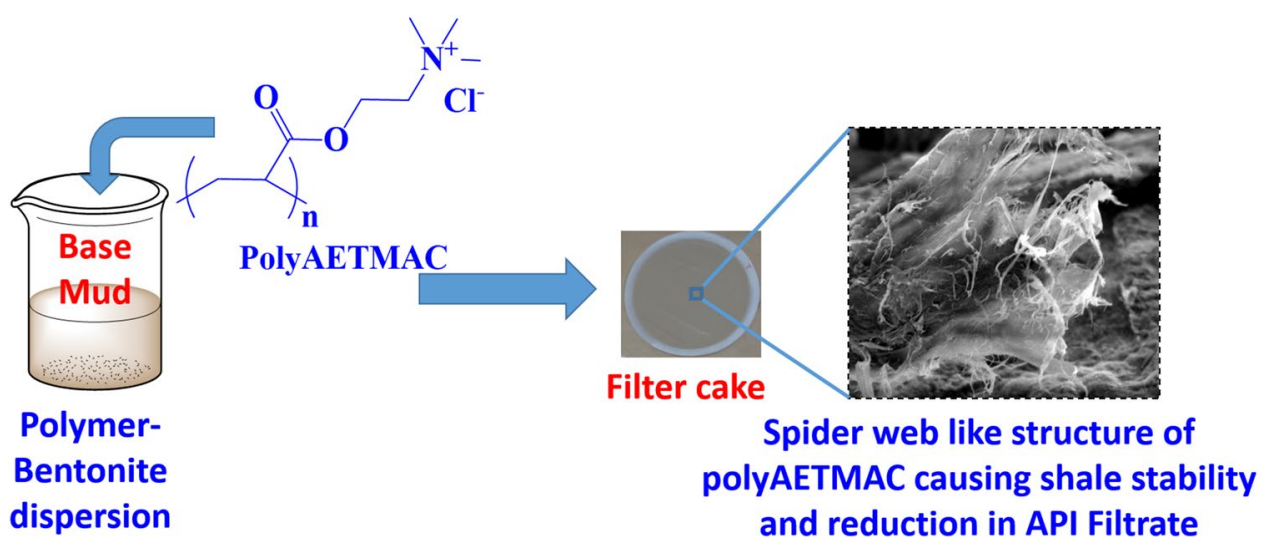

Keywords Drilling fluid $\cdot$ Shale $\cdot$ Wellbore instability $\cdot$ Cationic polymer $\cdot$ Capillary suction time $\cdot$ Linear swell meter

Shivanjali Sharma

shivanjali8888@gmail.com

\section{Abbreviations}

$\Phi_{300}$

Dial reading in viscometer at $300 \mathrm{rpm}$

$\Phi_{600}$

Extended author information available on the last page of the article 


\begin{tabular}{|c|c|}
\hline AETMAC & $\begin{array}{l}\text { [2-(acryloyloxy)ethyl]trimethylammonium } \\
\text { chloride }\end{array}$ \\
\hline AHR & After hot rolling \\
\hline AIBN & $\begin{array}{l}\text { 2,2'-Azobis(2-methylpropionitrile)/a,a'- } \\
\text { Azoisobutyronitrile }\end{array}$ \\
\hline AP & Apparent viscosity \\
\hline API & American Petroleum Institute \\
\hline APS & Ammonium persulphate \\
\hline BHR & Before hot rolling \\
\hline mPa.s & Centipoise \\
\hline CST & Capillary suction time/timer \\
\hline DMAPMA & $\begin{array}{l}N \text {-[3-(dimethylamino)propyl] } \\
\text { methacrylamide }\end{array}$ \\
\hline FESEM & $\begin{array}{l}\text { Field-emission scanning electron } \\
\text { microscopy }\end{array}$ \\
\hline LSM & Linear swell meter \\
\hline psi & Pound per square inch \\
\hline PV & Plastic viscosity \\
\hline $\mathrm{PAC}$ & Poly anionic cellulose \\
\hline $\mathrm{rpm}$ & Revolutions per minute \\
\hline WBM & Water-based mud \\
\hline YP & Yield point \\
\hline
\end{tabular}

\section{Introduction}

Water-based drilling fluids are cost effective and environment friendly compared to oil-based muds. However, these muds create wellbore instability problems in water-sensitive and highly reactive shale formations (O'Brien and Chenevert 1973). Over $75 \%$ of the formations drilled for petroleum exploration and production are comprised of shale and it causes about $70 \%$ of the wellbore instability problems across the world (Aftab et al. 2017), as the shale swell rapidly on absorption of water. Shales are essentially fine-grain sedimentary rocks composed of different clay minerals like kaolinite, illite, montmorillonite, and other minerals like quartz and calcite (Caenn et al. 2011; Feng et al. 2018). Due to absorption of water by clay minerals in shale, the shale swells that drastically changes the stress regime and the mechanical strength of shale formation decreases. This may result in collapsing of the wellbore during the drilling process. Inhibitive muds are drilling fluids that suppress hydration of clay which ultimately result in stabilized shale formation. Some of the examples are lime muds, gypsum muds, sea-water muds, and saturated salt-water muds (Gholizadeh-Doonechaly et al. 2009). One example of inhibitive WBM is silicate mud that consists of sodium or potassium silicate as the inhibitive component. Silicate anions combine with shale formation to stabilize the well bore by sealing microfractures, forming a silicate layer on shales and possibly acting as a less permeable membrane. This inhibit the water infiltration into formation and drilling a well through troublesome shale section is eased off that otherwise might require the use of oil-based mud (van Oort et al. 1996; Guo et al. 2006). Potassium ions also stabilize cuttings that may disintegrate by minimizing dispersion into finer particles. Inhibition is explained by the possible penetration of small non-hydrated ions into the porosity of the shale, thus forming an effective semi-permeable membrane (O'Brien and Chenevert 1973; Fink 2012; Gueciouer et al. 2017). Silicate systems have been used earlier too, but the control of rheological properties was difficult. Silicate muds along with potassium salt and polymer forms even more effective shale inhibitive combination with better rheological properties (Mahto and Sharma 2004; Patel et al. 2007; Khodja et al. 2010; Mahto et al. 2013). High-performance WBM containing amine-based polymers have been reported to have potential to be as effective as OBM. Amine-based compounds and polymers such as polyetherdiamines, hexamythylene diamine (HMDA), polyhydroxylated alkyl ammonium salts, polyethoxylated diamines etc. have been used in shale stabilization, but they have some limitations such as low inhibition, solid tolerance, and toxicity (Patel et al. 2007). Polyoxyalkyleneamine has also been used as a shale stabilizer for water-based drilling fluids that had no effect on filtration and rheological properties of water-based mud (Qu et al. 2009). Acrylamide-based polymers have also been reported to be effective in reducing API fluid loss and improving shale stability (Deville et al. 2011; Jain et al. 2017). Amine compounds with cationic sites are known to impart shale inhibition properties in mud and they act as clay stabilizer. Cationic amine compounds stabilize the shale by chemical interaction between cationic sites and anionic sites present on clay minerals in shale or by the cation exchange at single or multiple sites inside the porosity of shale or at the shale surface. The interaction is improved in case of oligomeric and polymeric amines due to multiple site adsorption onto the surface of shale. One advantage with oligomeric shale stabilizers is that they can enter the small pores of shale and stabilize the inner layers and block the water from entering shale pores (Gomez and Patel 2013). Oligomers of cationic amine may provide good shale inhibition through cation exchange and encapsulation mechanisms (Patel 2009). However, low-molecular-weight polymers may function as the shale stabilizer as well as rheology modifier. Smaller molecules of polymer can act as oligomers to stabilize inner layers of shale and covering large number of clay sites on shale surface that will result in better surface locking to minimize shale dispersion.

In this study, amine-based low-molecular-weight polymers have been developed to improve the inhibition capacity of water-based fluids, besides favoring the rheology and fluid loss control of the system. Free-radical polymerization of amine-based monomers and their characterization using various techniques and their application as a WBM additives 
has been reported. Shale used for the disintegration test was duly characterized by X-ray diffraction (XRD) and scanning electron microscopy (SEM) techniques. A base mud was prepared by dispersion of bentonite in water with some other additives used in drilling fluids such as sodium silicate and xanthan gum. Bentonite is a major additive for most water-based muds, and it contains sodium montmorillonite (a dioctahedral smectite) as a major component which gives unique colloidal and rheological properties (Cao et al. 2017). These polymers are added in the base mud formulation, to evaluate the effect of synthesized additives on rheological and filtration characteristics and most importantly on shale stabilization.

\section{Experimental}

\section{Materials}

Bentonite powder, ethanol (99.9\%), methanol (>99\%), potassium chloride (99\%), octanol-1 ( $>99 \%,<0.3 \% \mathrm{H}_{2} \mathrm{O}$ ), and sodium silicate $(97 \%)$ were all procured from SD Fine Chem Limited, Mumbai, India. Xanthan gum (>99.99\%) was purchased from HiMedia, Mumbai, India. These chemicals were synthesis grade and were used as obtained. Initiator ammonium persulphate (AP, $>98 \%$ ) and monomers $\mathrm{N}$-[3-(dimethylamino)propyl] methacrylamide (DMAPMA, 99\%) and [2-(acryloyloxy)ethyl]trimethylammonium chloride (AETMAC, $80 \mathrm{wt} \%$ in $\mathrm{H}_{2} \mathrm{O}$ ) purchased from SigmaAldrich, India were used as obtained without further purification to synthesize polymers. a, a'-Azoisobutyronitrile (AIBN, > 98\%) initiator procured from Spectrochem Pvt. Ltd., Mumbai, India was used after recrystallization in methanol. Polyanionic cellulose regular grade (PAC-RG) was provided by Oil and Natural Gas Corporation Ltd, India.

\section{Synthesis of polymers}

\section{Synthesis of poly[3-(dimethylamino) propyl] methacrylamide [polyDMAPMA]}

DMAPMA (10.0 g, $58.74 \mathrm{mmol})$ was taken in ethanol $(45 \mathrm{~mL})$ in a two neck round bottom flask. The mixture was heated to $60{ }^{\circ} \mathrm{C}$ with nitrogen purging on, and after $30 \mathrm{~min}$ of purging, AIBN $(0.0985 \mathrm{~g}, 0.6 \mathrm{mmol})$ was added into the solution. The reaction was carried out for $48 \mathrm{~h}$, and then, the mixture was transferred into a beaker containing acetone for precipitation. The precipitate was washed with n-hexane to remove unreacted monomers. The white mass obtained was further purified by dissolving in THF and reprecipitating in acetone before drying in vacuum. Yield: $72.4 \%$. ${ }^{1} \mathrm{H}$ NMR (400 MHz, $\left.\mathrm{D}_{2} \mathrm{O}\right) \delta(\mathrm{ppm}): 3.5\left(2 \mathrm{H}, \mathrm{NHCH}_{2} \mathrm{CH}_{2}\right)$, $3.1\left(1 \mathrm{H}, \mathrm{CH}_{2} \mathrm{CHCOCH}_{2}\right), 2.3\left[2 \mathrm{H}, \mathrm{CH}_{2} \mathrm{~N}\left(\mathrm{CH}_{3}\right)_{2}\right], 2.1[6 \mathrm{H}$,
$\left.\mathrm{CH}_{2} \mathrm{~N}\left(\mathrm{CH}_{3}\right)_{2}\right], 1.6\left[2 \mathrm{H}, \mathrm{CH}_{2} \mathrm{CH}_{2} \mathrm{~N}\left(\mathrm{CH}_{3}\right)_{2}\right]$, and $1.1(2 \mathrm{H}$, $\mathrm{CHCH}_{2} \mathrm{CH}$ ), FT-IR $\left(\mathrm{cm}^{-1}\right) 1634$ (CO stretching, amide) and 1519 (NH deformation, amide), $\mathrm{M}_{\mathrm{n}}(\mathrm{GPC}$, water $)=5484 \mathrm{~g} /$ $\mathrm{mol}, \mathrm{PDI}=2.1$.

\section{Synthesis of poly[2-(acryloyloxy)ethyl]trimethylammonium chloride [PolyAETMAC]}

PolyAETMAC was synthesized by free-radical polymerization, where ammonium persulphate (APS) was used as initiator for the reaction. AETMAC $(5.0 \mathrm{~g}, 25.83 \mathrm{mmol})$ was taken in deionized water $(40 \mathrm{~mL})$ and kept under $\mathrm{N}_{2}$ atmosphere. To this, APS $(0.0571 \mathrm{~g}, 0.25 \mathrm{mmol})$ was added with stirring. The solution was stirred for $24 \mathrm{~h}$ at $400 \mathrm{rpm}$ and $70{ }^{\circ} \mathrm{C}$. The milk white polymer obtained was precipitated in methanol. The white mass was redissolved in deionized water and precipitated in methanol to remove low-molecularweight impurities. The final polymer was dried under vacuum before further use. Yield: $55.6 \% .{ }^{1} \mathrm{H}$ NMR $(400 \mathrm{MHz}$, $\left.\mathrm{D}_{2} \mathrm{O}\right) \delta(\mathrm{ppm}): 4.6\left(2 \mathrm{H}, \mathrm{COOCH}_{2}\right), 3.8\left(2 \mathrm{H}, \mathrm{COOCH}_{2} \mathrm{CH}_{2}\right)$, $3.3\left[9 \mathrm{H}, \mathrm{CH}_{2} \mathrm{~N}^{+}\left(\mathrm{CH}_{3}\right)_{3}\right], 2.6\left(1 \mathrm{H}, \mathrm{CH}_{2} \mathrm{CHCOCH}_{2}\right)$, and 1.9 $\left(2 \mathrm{H}, \mathrm{CHCH}_{2} \mathrm{CH}\right)$, FT-IR $\left(\mathrm{cm}^{-1}\right) 1710$ (CO stretching, ester), $\mathrm{M}_{\mathrm{n}}(\mathrm{GPC}$, water $)=3758 \mathrm{~g} / \mathrm{mol}, \mathrm{PDI}=2.4$. PolyAETMAC after purification and vacuum drying is shown in Fig. 1.

\section{Polymer characterization}

The FT-IR spectra of the samples were recorded using a PerkinElmer Spectrum Two spectrometer. All the samples were tested using "attenuated total reflectance" (ATR) mode using PIKE MIRacle single-reflection horizontal ATR accessory equipped with a ZnSe ATR crystal. ${ }^{1} \mathrm{H}$ NMR spectra

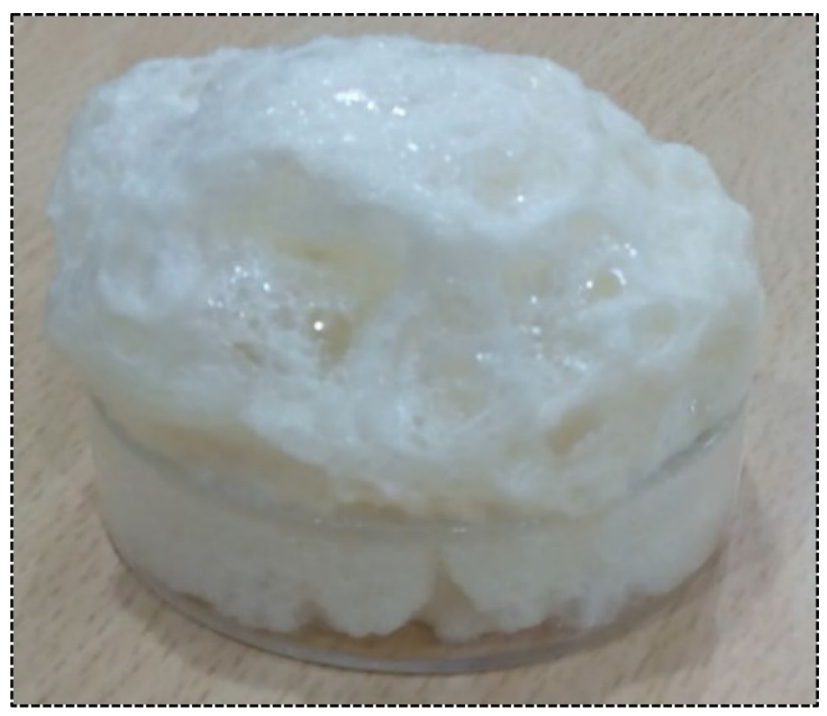

Fig. 1 Synthesized polyAETMAC after drying in vacuum desiccator at normal temperature 
were obtained on a JEOL ECS400 NMR spectrometer with $\mathrm{D}_{2} \mathrm{O}$ as solvent and spectra were recorded at $400 \mathrm{MHz}$. Gel permeation chromatography (GPC) was done using Agilent 1260 MDS RI equipment at a temperature of $40{ }^{\circ} \mathrm{C}$. Test was conducted using a water column and sodium nitrate and sodium dihydrogen phosphate dihydrate eluent. The volume injected was $100 \mu \mathrm{L}$, and data were recorded for a $15 \mathrm{~min}$ runtime. Thermogravimetric analysis (TGA) of the polymer samples was conducted on TA 2050 thermal gravimetric analyser with the help of DTG-60 H detector under the nitrogen atmosphere, and alumina cell was used for the TGA characterization. Heating rate was kept to be $20^{\circ} \mathrm{C} / \mathrm{min}$.

\section{Rheology of polymers}

For understanding the effect of temperature on the polymer clay interaction, frequency sweep analysis was done using Anton Paar MCR 52 Rheometer. A constant shear strain of $0.5 \%$ was applied, and angular frequency was varied from 1 to $100 \mathrm{rad} / \mathrm{s}$ for each test temperatures. A clay dispersion containing $1.0 \mathrm{w} / \mathrm{v} \%$ bentonite was prepared which contained $0.5 \mathrm{w} / \mathrm{v} \%$ of polymer. Viscosity measurements of the aqueous polymer solutions were also done before and after heating the samples for $1 \mathrm{~h}$ at $110^{\circ} \mathrm{C}$.

\section{Shale characterization}

Field-emission scanning electron microscopy (FESEM) images of shale and filter cakes were recorded using JEOL JXA-8230 Electron Probe Micro-analyser at $5.0 \mathrm{kV}$ and $12.5 \mathrm{kV}$, respectively. X-ray diffraction of shale was carried out in PANalytical X'Pert PRO, Spectris plc X-ray diffractometer with a scan range of $10^{\circ}-80^{\circ}$. Powdered shale was used for XRD analysis.

\section{Mud preparation}

A thick bentonite dispersion in water $(\sim 10 \mathrm{w} / \mathrm{v} \%)$ was prepared using a Hamilton beach mixer. It was then allowed to swell by complete hydration over a period of $24 \mathrm{~h}$. This prehydrated bentonite suspension (PHBS) was used to make $5.0 \mathrm{mPa}$.s apparent viscosity PHBS by adding required amount of water in Hamilton beach mixer. Base mud was prepared by the mixing various mud additives into this $5.0 \mathrm{mPa}$.s PHBS with the help of Hamilton Beach Mixer. Composition of base mud is given in Table 1. Base mud was mixed with polyDMAPMA or polyAETMAC in varying concentration, from 0.125 to $0.625 \mathrm{w} / \mathrm{v} \%$, to prepare five different muds based on each type of polymer. Few drops of Octanol-1 were added as required to suppress the formation of foam while mixing the mud additives.
Table 1 Base mud additives mixed in PHBS

\begin{tabular}{llll}
\hline S. no. & Additive & Quantity (w/v\%) & Key function \\
\hline 1 & Xanthan Gum & 0.25 & Viscosifier \\
2 & PAC-RG & 0.50 & $\begin{array}{c}\text { Fluid loss } \\
\text { reducer and } \\
\text { viscosifier } \\
\end{array}$ \\
& & & Shale stabilizer \\
3 & KCl & 4.00 & Shale stabilizer \\
4 & Sodium silicate & 4.00 & Defoamer \\
5 & Octanol & As needed & \\
\hline
\end{tabular}

\section{Mud characterization}

\section{Rheology}

FANN viscometer model 35 was used to measure the rheological parameters of mud formulations. This instrument gives an accurate estimate of apparent viscosity (AV), plastic viscosity (PV), and yield point (YP) that is attained by reading the deflection of viscometer dial $(\Phi)$ at different rpm (Saboori et al. 2018). It also gives the gel strength of drilling muds. After mixing the mud properly at $600 \mathrm{rpm}$, initial and final gel strengths (in $\mathrm{lb} / 100 \mathrm{ft}^{2}$ ) are indicated by maximum dial deflection at $3 \mathrm{rpm}$ after mud has been at rest for $10 \mathrm{~s}$ and $10 \mathrm{~min}$, respectively. Rheological parameters based on Bingham Plastic model can be calculated by following formulae:

$\mathrm{AV}=\Phi_{600} / 2$

$\mathrm{PV}=\Phi_{600}-\Phi_{300}$

$\mathrm{YP}=\Phi_{300}-\mathrm{PV}$.

\section{API filtrate}

Series 300 LPLT filter press by FANN Instrument Company was used to determine the filtrate volume from drilling mud sample. It gives an indication of the ability of drilling fluid to refrain the water from entering into clay containing formations which are water sensitive. A pressure of 100 psi $\left(6.895 \times 10^{5} \mathrm{~Pa}\right)$ and normal temperature is maintained during this test and filtrate collected in $30 \mathrm{~min}$ is reported as API fluid loss.

\section{Hot-rolling dispersion}

Hot-rolling dispersion test (shale disintegration test or shale dispersion test) is one of the most widely used method for optimizing a drilling fluid for shale stabilization. It consists of adding a known quantity of cuttings into a fixed volume of mud contained in an ageing cell made of steel. Ageing 
cell is rolled at a certain rpm and temperature for $16 \mathrm{~h}$; the shale is then recovered on a sieve. The amount of recovered shale is expressed as a percentage of original weight of shale which indicates the amount disintegrated in hot-rolling test (Khodja et al. 2010). High-percent recoveries are indicative of inhibitive fluids. Clearly, with a poorly inhibitive fluid, cuttings will disperse into the fluid and very low percentage of cuttings will be recovered. In the present study, $400 \mathrm{~mL}$ mud was poured into ageing cell and $10 \mathrm{~g}$ of shale cuttings with mesh size greater than $10 \mathrm{BSS}$ were also mixed with mud for shale dispersion test and hot rolled at $100{ }^{\circ} \mathrm{C}$ for $16 \mathrm{~h}$ at $30 \mathrm{rpm}$. Recovered shale cuttings were gently washed with water and dried in a hot air oven for $2 \mathrm{~h}$ at a temperature of $105^{\circ} \mathrm{C}$ to remove the moisture.

\section{Linear swell meter test}

FANN Linear Swell Meter, Model 2000 with four channels was used to determine the shale swelling by interaction of water-based mud with clay present in the shale. The shale was taken from the depth of 2100-2700 m of Cambay basin located in western India. Shale was grounded into less than 200 BSS mesh size powder, and then, $20.0 \mathrm{~g}$ of shale powder was placed in a cylindrical die and compressed by hydraulic press (Make-OFITE) at 10,000 psi $\left(6.895 \times 10^{7} \mathrm{~Pa}\right)$ for $30 \mathrm{~min}$. Cylindrical shale pellets were used to perform the swelling test. These compacted shale pellets were immersed in various fluids to determine the percentage of swelling in $2.0 \mathrm{~h}$ by fluid interaction with clay present in shale pellet. The thickness of cylindrical shale pellets was measured to be $0.571,0.572,0.570$, and 0.565 inch. These compacted shale sample were immersed in water, water + sodium silicate $(8.0$ $\mathrm{w} / \mathrm{v} \%)$, water + sodium silicate $(8.0 \mathrm{w} / \mathrm{v} \%)+$ polyDMAPMA $(0.50 \mathrm{w} / \mathrm{v} \%)$, and water + sodium-silicate $(8.0 \mathrm{w} / \mathrm{v} \%)$ polyAETMAC $(0.50 \mathrm{w} / \mathrm{v} \%)$ to measure the swelling percentage.

\section{Capillary suction time test}

Capillary suction time test measures the time required by water-based drilling fluid filtrate to travel a given distance on thick porous chromatography grade filter paper (Whatman \#17). The equipment automatically determines the time for filtrate to travel between electrodes that are located 0.5 and $1.0 \mathrm{~cm}$ from the edge of the cylinder when a fixed area of blotter paper is exposed to the test sample. This method gives an indication of how shale is interacting with the water present in mud. In the presence of additives for shale stabilization, lesser amount of water is absorbed by shale resulting in a decrease in CST value. Therefore, lower CST value means that shale stabilizer is more effective. In this test, $10 \mathrm{~mL}$ mud sample was diluted to $50 \mathrm{~mL}$ by adding water and mixed with $2.0 \mathrm{~g}$ shale powder (passing $100 \mathrm{BSS}$ mesh size) using a waring blender. The slurry was mixed for
$5 \mathrm{~min}$ and allowed to hydrate for $30 \mathrm{~min}$; after then, it was again mixed for $1 \mathrm{~min}$, and immediately, the sample was tested by placing $5 \mathrm{~mL}$ of sample into CST sample holder. Test was repeated for three times, and average values were noted down. CST was done for base mud, base mud with a concentration of $0.5 \mathrm{w} / \mathrm{v} \%$ of both polymers, and base mud with an additional $5.0 \mathrm{w} / \mathrm{v} \%$ of $\mathrm{KCl}$ which is a conventional shale stabilizer.

\section{Results and discussion}

\section{Polymer characterization}

FT-IR spectra of DMAPMA monomer and its polymer are shown in Fig. 2. Spectra showed a wide absorption band at $\sim 3400 \mathrm{~cm}^{-1}$ accountable to the NH-stretching vibrations. The peaks at 1634 and $1519 \mathrm{~cm}^{-1}$ attributed to $\mathbf{C}=\mathbf{O}$-stretching vibration and $\mathbf{N H}$ deformation vibrations in the - $\mathbf{C O N H}_{2}$ group, respectively. The disappearance of band at $1605 \mathrm{~cm}^{-1}$ for the $\mathrm{C}=\mathrm{C}$ linkage after polymerization supported the formation of polymer. The band for $\mathrm{C}-\mathrm{H}$-bending vibration of the $-\mathrm{CH}_{2}-$ linkages in monomer shifted by $10 \mathrm{~cm}^{-1}$ after polymerization. Similarly, FT-IR spectra of AETMAC and corresponding homopolymer are shown in Fig. 3. Bands at $1555 \mathrm{~cm}^{-1}$ attributed to $\mathbf{C}=\mathbf{C}$ are absent in polymer spectra, suggesting the formation of polymer by free radical. The $\mathbf{C}=\mathbf{O}$ band shifted from 1725 to $1710 \mathrm{~cm}^{-1}$ after polymerization. In case of ${ }^{1} \mathrm{H}$ NMR spectra, no peaks were visible in between 5 and 6 ppm suggesting close to quantitative removal of monomers in the polymer (Fig. 4). Appearance of broad peaks at $\sim 2$ ppm suggested the formation of $\mathrm{CH}_{2}-\mathrm{CH}_{2}$ linkages after polymerization. Similarly, for polyDMAPMA, the intensity of resonances in between 5 and 6 ppm notably decreased and new peaks at 2.7 and $1.1 \mathrm{ppm}$ appeared

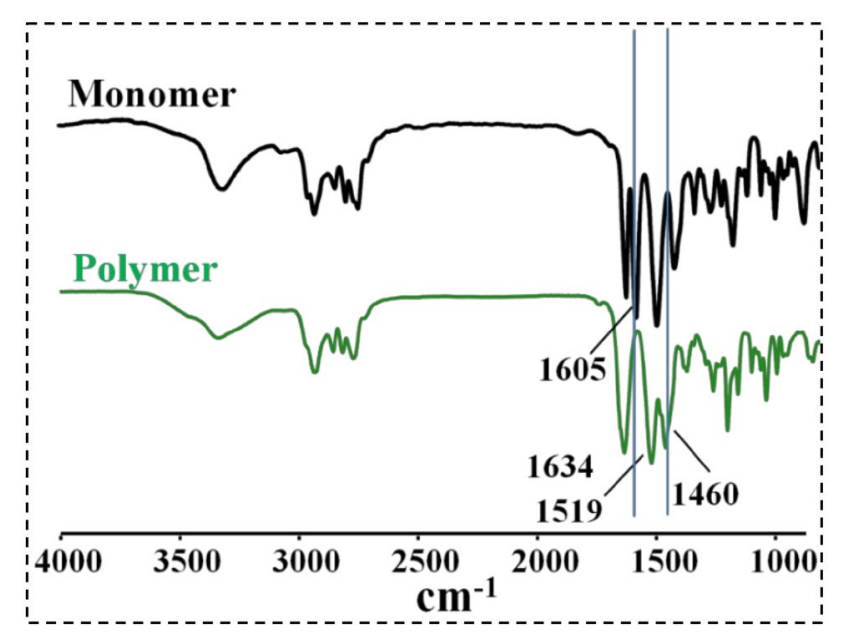

Fig. 2 FT-IR spectra of DMAPMA and its polymer

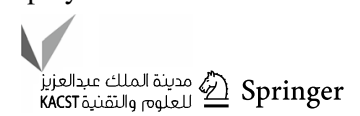




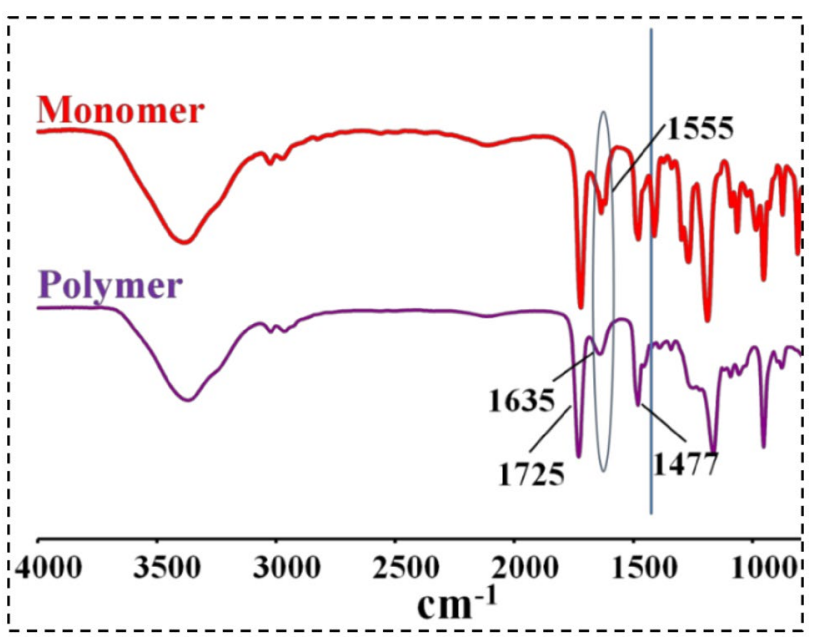

Fig. 3 FT-IR spectra of AETMAC monomer and its polymer

suggesting successful polymerization. GPC data revealed that the number average molecular weight of polyDMAPMA and polyAETMAC is 5484 and $3758 \mathrm{~g} / \mathrm{mol}$, respectively (Fig. 5). The molecular-weight distribution is broad with PDI values for both polymers close to 2 . Figure 6 shows the variation of mass percentage of polymer samples with the temperature. The polymers exhibited thermal stability up to $250{ }^{\circ} \mathrm{C}$ with $\leq 20 \mathrm{wt} \%$ loss in total mass. The initial weight loss may be attributed to the evaporation of moisture during the initial heating period. polyAETMAC being more hygroscopic due to the presence of quaternary amine functionality exhibited somewhat higher mass loss $(\sim 20 \mathrm{wt} \%)$ compared to that of the polyDMAPMA ( $10 \mathrm{wt} \%)$ up to $250^{\circ} \mathrm{C}$. However, sharp decrease in weight was observed in the range of $260-300{ }^{\circ} \mathrm{C}$ and the samples lost up to $50 \mathrm{wt} \%$ of the total mass suggesting structural degradation.

Mozaffari et al. $(2015,2016,2017)$ have already studied the effect of additives on the complex fluids using rheological analysis. Similarly, Liu et al. (2017) have also reported the modulus dependency on concentration of polymeric additives. To investigate the temperature dependency of interaction between polymer and clay minerals, we performed frequency sweep analysis of $1.00 \mathrm{w} / \mathrm{v} \%$ clay dispersion in water containing $0.5 \mathrm{w} / \mathrm{v} \%$ of polymers at four different temperatures. Storage modulus of polyAETMAC containing clay dispersion was higher than that of polyDMAPMA containing clay dispersion (Fig. 7). It suggested the presence of stronger interaction between clay minerals and the charged quaternary amine moieties present in polyAETMAC polymer than the interactive forces between polyDMAPMA polymer possessing neutral substituted amine functionalities and clay minerals. Furthermore, on gradually increasing the temperature from 30 to $60^{\circ} \mathrm{C}$, storage modulus of polyAETMAC containing sample increased significantly and that of polyDMAPMA containing sample remained unaltered. This can be attributed to the network expansion of polyAETMAC at higher temperature owing to the strong interactive forces between clay platelets and cationically charged quaternary amines present in polyAETMAC polymer chains. The data further supported that the
Fig. $4{ }^{1} \mathrm{H}$ NMR spectra of polymers recorded using $\mathrm{D}_{2} \mathrm{O}$ solvent

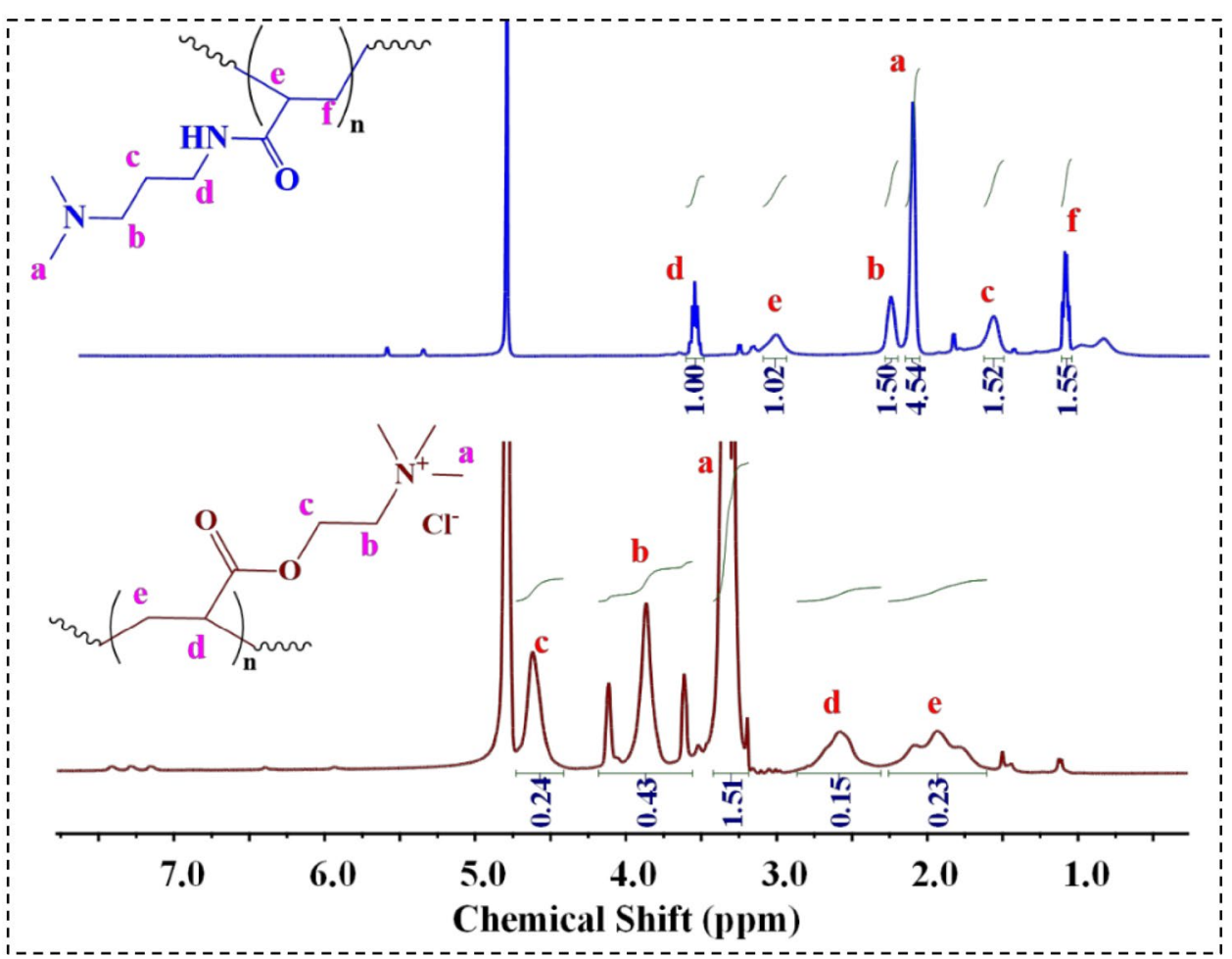




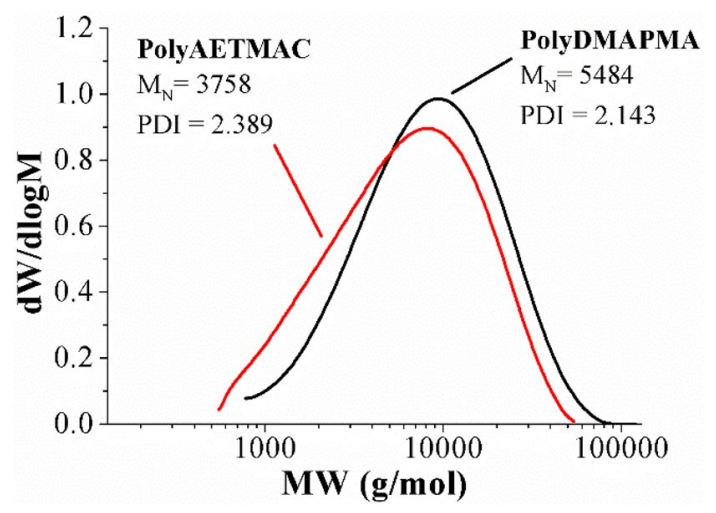

Fig. 5 Gel permeation chromatography results of both homopolymers

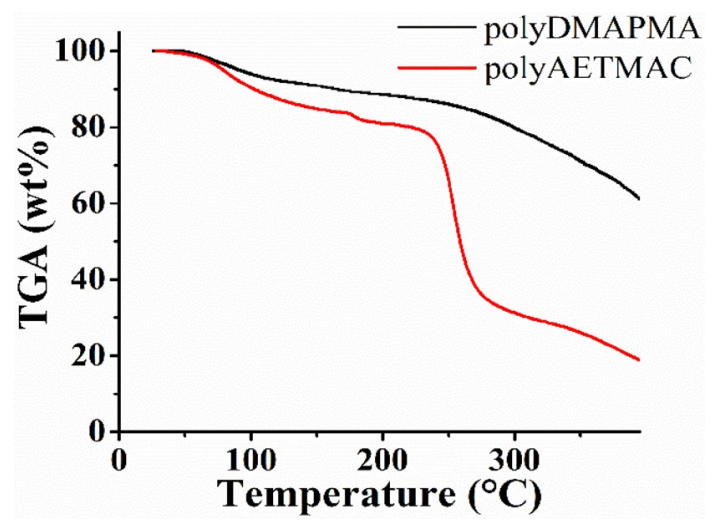

Fig. 6 Thermal gravimetric analysis of polymer samples

cationically charged polymer may be a suitable additive in high-temperature reservoirs and the rheological parameters of the resulting drilling fluid may improve owing to the stronger interactive forces present in the system.

To check the stability in solution, $1.00 \mathrm{w} / \mathrm{v} \%$ aqueous solution of both polymers was prepared and kept for 1 week. There was no change in its appearance, and no precipitation was observed (Fig. 8). We also performed the viscosity measurement of these solutions when freshly prepared and then after heating at $110^{\circ} \mathrm{C}$ for $1 \mathrm{~h}$ (Fig. 9). It was found that the reduction in viscosity was negligible which confirms the stability of polymers in solution up to $110^{\circ} \mathrm{C}$.

\section{Shale characterization}

Shale sample was characterized using X-ray diffraction (XRD) analysis to quantify the minerals present. XRD plot of major minerals present in shale has been reported in the previous work (Beg et al. 2018), where the presence of water-sensitive clay minerals in shale was confirmed. Various key minerals present in studied shale are given in Table 2. Kaolinite and Illite are clay minerals which are responsible for shale dispersion and swelling in the presence of water-based mud.

Shale cutting was also characterized for surface morphology using field-emission scanning electron microscopy (FESEM) analysis. FESEM image is shown in Fig. 10. There are tiny pores and fractures ranging from less than a micron to more than 10 microns in shale through which water is invaded into the shale and interacts with clay minerals. This results into shale swelling and disintegration which may be controlled by blocking these pores effectively.

\section{Rheology}

Rheological parameters of drilling fluid such as apparent viscosity ( $\mathrm{AV}$ ), plastic viscosity (PV), yield point (YP), and gel strength are critical for drilling operation and need close monitoring throughout the process. A decrease in AV affects cutting carrying capacity of fluid. In addition, very high AV may lead to higher pumping costs. PV is the resistance to flow of drilling fluid which is caused by mechanical friction within the fluid. This mechanical friction within the fluid can be due to interaction between liquid and solid particles or between solid particles or due to deformation of liquid particles under shear stress. PV affects the rate of penetration and it should be low (preferably $<30 \mathrm{mPa} . \mathrm{s}$ ) for acceptable rate of drilling (Khodja et al. 2010). YP is essential for efficient removal of cuttings from the wellbore and typical silicate mud have value of YP in the range of 9-15 Pa (Guo et al. 2006). For the formulations containing polyDMAPMA, rheological parameters obtained before hot rolling (BHR) and after hot rolling (AHR) at $100{ }^{\circ} \mathrm{C}$ are listed in Table 3 . It was found that rheological properties of all the formulations reduced due to $16 \mathrm{~h}$ ageing at $100{ }^{\circ} \mathrm{C}$. This happens due to the thermal degradation of the biopolymers used in drilling fluids. Xanthan gum and PAC degrade up to some extent due to the prolonged exposure to high temperature (Caenn et al. 2011). AV of base mud was reduced by $\sim 25 \%$ AHR, whereas that of formulation containing $2.5 \mathrm{~g}$ polyDMAPMA decreased by 29\% AHR. However, the issue may be addressed by supplementing the polymer content in a later stage as a part of make up additives. AV of base mud increased by $\sim 25 \%$ on the addition of $0.625 \%(\mathrm{w} / \mathrm{v})$ of polyDMAPMA before hot rolling and this enhancement stood at $\sim 19 \%$ after hot rolling for $16 \mathrm{~h}$. There was an increase in all rheological properties of mud with increasing concentration of polyDMAPMA. PV and YP improved by $~ 36 \%$ and $\sim 15 \%$, respectively, for a dose of $0.625 \%(\mathrm{w} / \mathrm{v})$ in base mud. Even after hot-rolling test, YP for a concentration of $0.625 \mathrm{w} / \mathrm{v} \%$ was $23 \mathrm{~Pa}$ with polyDMAPMA and $25 \mathrm{~Pa}$ with polyAETMAC which is better than a typical silicate mud for efficient hole cleaning. Impact on gel strength was not much pronounced, but it was also increasing with polymer concentration. Gel strength values remained in acceptable

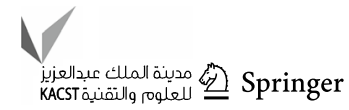


Fig. 7 Variation of storage modulus profile and loss modulus profile of aqueous polymer-clay dispersion with temperature
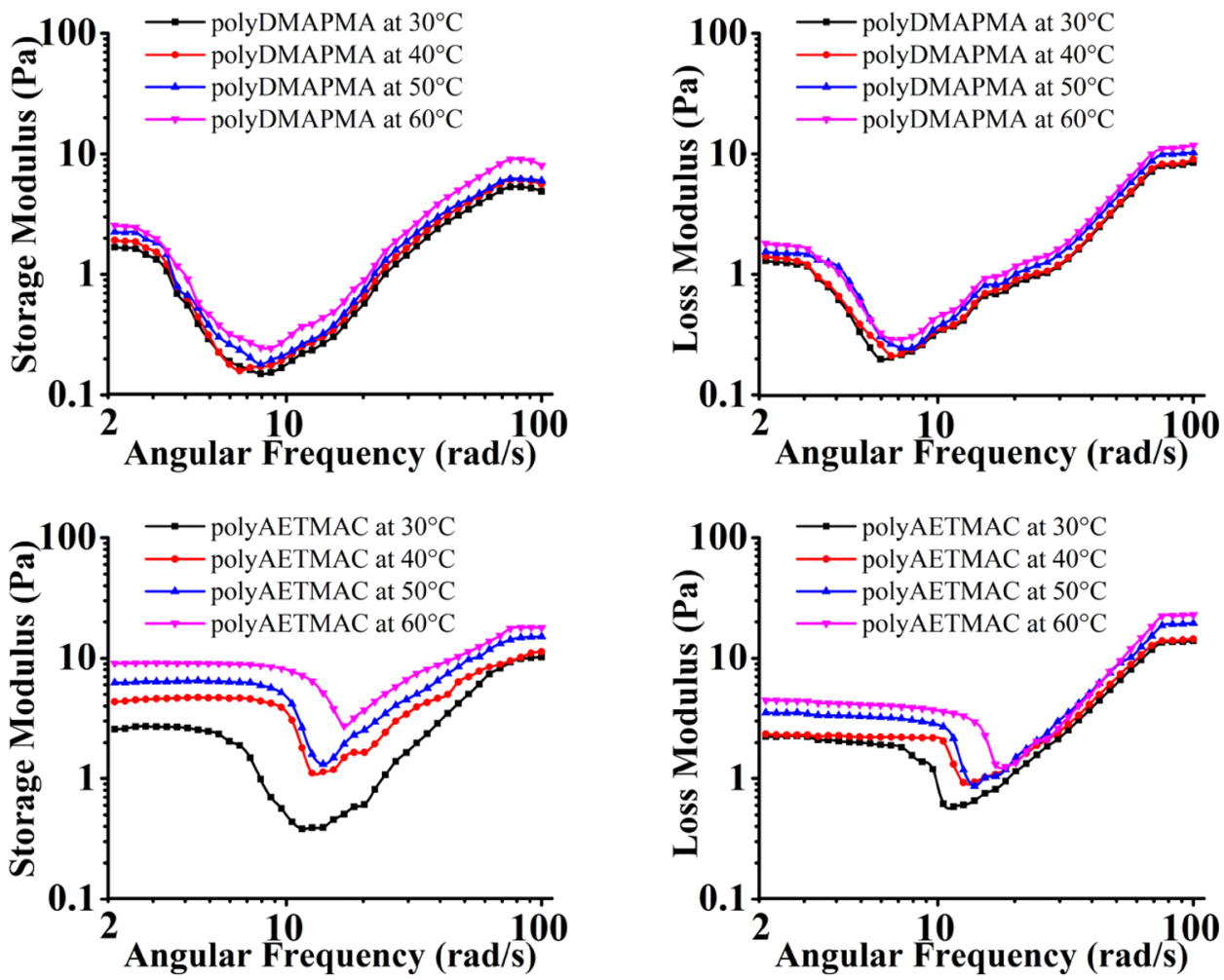

(a)

polyDMAPMA polyAETMAC
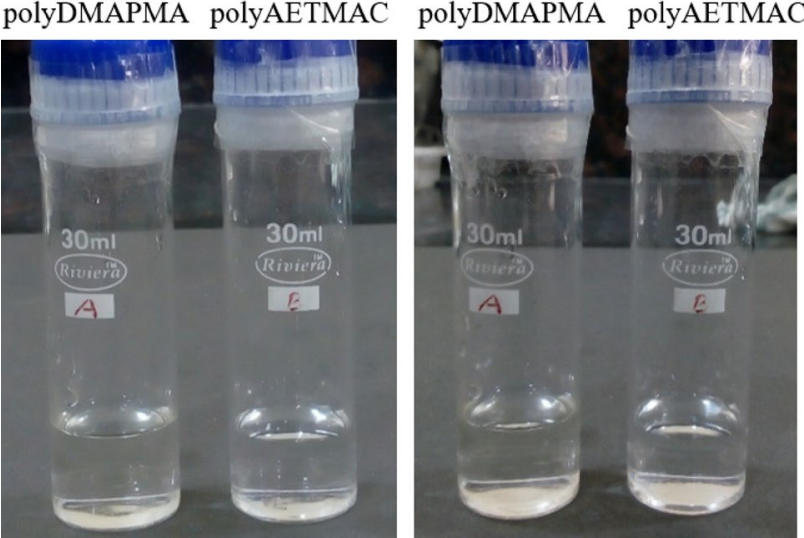

Fig. 8 Polymer solution in water (a) freshly prepared and (b) after 1 week

range of 7-15 lb/100ft ${ }^{2}$ (3.3516-7.182 Pa) (Guo et al. 2006; Khodja et al. 2010). Lower values of gel strength results in settling of drill cuttings when the circulation is stopped, and therefore, they should be higher than a minimum value. In the present case, gel strength was higher than $7 \mathrm{lb} / 100 \mathrm{ft}^{2}$ (3.3516 Pa) even after hot rolling for $16 \mathrm{~h}$. For mud formulations containing polyAETMAC, enhancement in rheological properties was marginally greater in magnitude than that in the presence of polyDMAPMA (Table 4). Even after hot

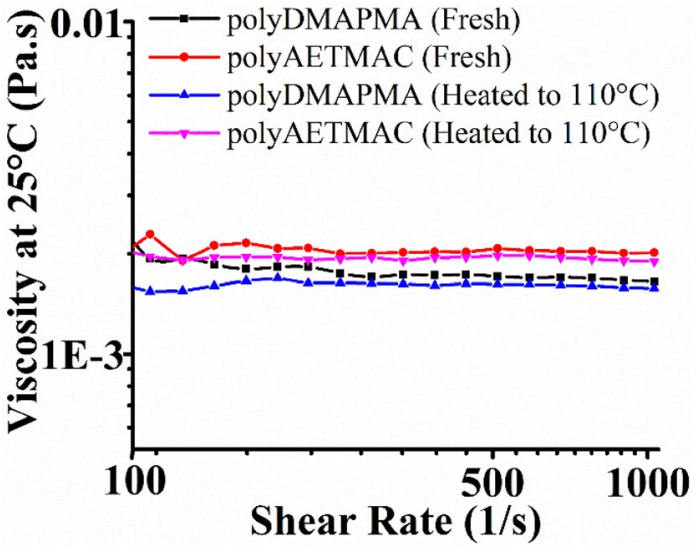

Fig. 9 Viscosity profile of freshly prepared aqueous solution and after heating for $1 \mathrm{~h}$ at $110^{\circ} \mathrm{C}$

Table 2 Weight fraction of major minerals present in shale

\begin{tabular}{lll}
\hline S. No. & Mineral & Weight fraction \\
\hline 1 & Mica & 0.39 \\
2 & Quartz & 0.32 \\
3 & Kaolinite & 0.18 \\
4 & Illite & 0.11 \\
\hline
\end{tabular}


Fig. 10 Scanning electron microscopic (SEM) images of shale sample performed at room temperature and at high voltages of $12.5 \mathrm{kV}$ and $10 \mathrm{kV}$, respectively

Table 3 Rheological performance of various drilling muds containing polyDMAPMA

Table 4 Rheological performance of various drilling muds containing polyAETMAC

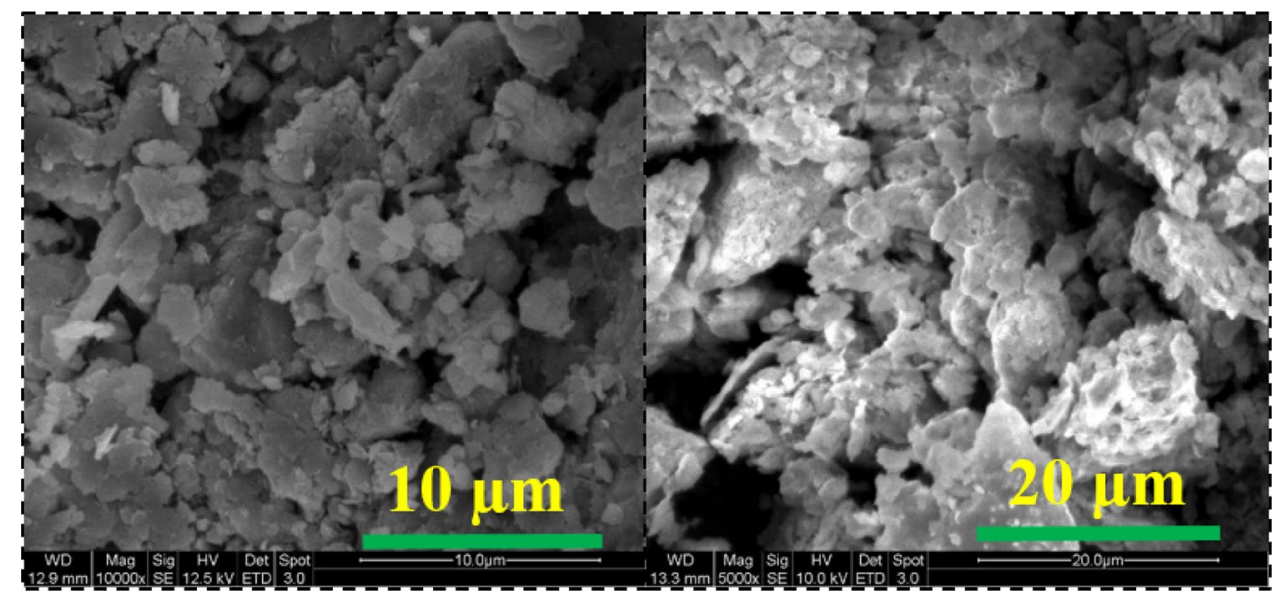

\begin{tabular}{|c|c|c|c|c|c|c|c|c|}
\hline \multirow[t]{2}{*}{ S.N. } & \multirow[t]{2}{*}{ Parameter } & \multirow[t]{2}{*}{ Condition } & \multicolumn{6}{|c|}{ Formulations with polyDMAPMA (g/400 mL) } \\
\hline & & & 0 & 0.5 & 1.0 & 1.5 & 2.0 & 2.5 \\
\hline \multirow[t]{2}{*}{1} & \multirow[t]{2}{*}{$\Phi_{600}$} & BHR & 55 & 56 & 58 & 61 & 65 & 69 \\
\hline & & AHR & 41 & 41 & 43 & 44 & 47 & 49 \\
\hline \multirow[t]{2}{*}{2} & \multirow[t]{2}{*}{$\Phi_{300}$} & BHR & 41 & 42 & 43 & 45 & 47 & 50 \\
\hline & & AHR & 30 & 30 & 32 & 33 & 35 & 36 \\
\hline \multirow[t]{2}{*}{3} & \multirow[t]{2}{*}{ AV (mPa.s) } & BHR & 27.5 & 28.0 & 29.0 & 30.5 & 32.5 & 34.5 \\
\hline & & AHR & 20.5 & 20.5 & 21.5 & 22.0 & 23.5 & 24.5 \\
\hline \multirow[t]{2}{*}{4} & \multirow[t]{2}{*}{ PV (mPa.s) } & BHR & 14 & 14.0 & 15.0 & 16.0 & 18.0 & 19.0 \\
\hline & & AHR & 11 & 11.0 & 11.0 & 11.0 & 12.0 & 13.0 \\
\hline \multirow[t]{2}{*}{5} & \multirow[t]{2}{*}{ YP (lb/100ft $\left.{ }^{2}, 0.4788 \mathrm{~Pa}\right)$} & BHR & 27 & 28.0 & 28.0 & 29.0 & 29.0 & 31.0 \\
\hline & & AHR & 19 & 19.0 & 21.0 & 22.0 & 23.0 & 23.0 \\
\hline \multirow[t]{2}{*}{6} & \multirow[t]{2}{*}{ Gel $0\left(\mathrm{lb} / 100 \mathrm{ft}^{2}, 0.4788 \mathrm{~Pa}\right)$} & BHR & 12 & 13 & 14 & 14 & 15 & 16 \\
\hline & & AHR & 7 & 6 & 7 & 9 & 9 & 10 \\
\hline \multirow[t]{2}{*}{7} & \multirow{2}{*}{ Gel $10\left(\mathrm{lb} / 100 \mathrm{ft}^{2}, 0.4788 \mathrm{~Pa}\right)$} & BHR & 24 & 27 & 28 & 29 & 31 & 33 \\
\hline & & AHR & 10 & 11 & 11 & 13 & 14 & 15 \\
\hline
\end{tabular}

S.N. Parameter

Condition Formulations with polyAETMAC $(\mathrm{g} / 400 \mathrm{~mL})$

\begin{tabular}{|c|c|c|c|c|c|c|c|c|}
\hline & & & 0 & 0.5 & 1.0 & 1.5 & 2.0 & 2.5 \\
\hline \multirow[t]{2}{*}{1} & \multirow[t]{2}{*}{$\Phi_{600}$} & BHR & 55 & 57 & 59 & 62 & 67 & 71 \\
\hline & & AHR & 41 & 43 & 45 & 48 & 50 & 53 \\
\hline \multirow[t]{2}{*}{2} & \multirow[t]{2}{*}{$\Phi_{300}$} & BHR & 41 & 42 & 43 & 45 & 48 & 51 \\
\hline & & AHR & 30 & 32 & 33 & 35 & 37 & 39 \\
\hline \multirow[t]{2}{*}{3} & \multirow[t]{2}{*}{$\mathrm{AV}$ (mPa.s) } & BHR & 27.5 & 28.5 & 29.5 & 31.0 & 33.5 & 35.5 \\
\hline & & AHR & 20.5 & 21.5 & 22.5 & 24.0 & 25.0 & 26.5 \\
\hline \multirow[t]{2}{*}{4} & \multirow[t]{2}{*}{ PV (mPa.s) } & BHR & 14 & 15.0 & 16.0 & 17.0 & 19.0 & 20.0 \\
\hline & & AHR & 11 & 11.0 & 12.0 & 13.0 & 13.0 & 14.0 \\
\hline \multirow[t]{2}{*}{5} & \multirow[t]{2}{*}{$\mathrm{YP}\left(\mathrm{lb} / 100 \mathrm{ft}^{2}, 0.4788 \mathrm{~Pa}\right)$} & BHR & 27 & 27.0 & 27.0 & 28.0 & 29.0 & 31.0 \\
\hline & & AHR & 19 & 21.0 & 21.0 & 22.0 & 24.0 & 25.0 \\
\hline \multirow[t]{2}{*}{6} & \multirow[t]{2}{*}{ Gel $0\left(\mathrm{lb} / 100 \mathrm{ft}^{2}, 0.4788 \mathrm{~Pa}\right)$} & BHR & 12 & 14 & 15 & 16 & 16 & 17 \\
\hline & & AHR & 7 & 7 & 8 & 9 & 11 & 12 \\
\hline \multirow[t]{2}{*}{7} & \multirow[t]{2}{*}{ Gel $10\left(\mathrm{lb} / 100 \mathrm{ft}^{2}, 0.4788 \mathrm{~Pa}\right)$} & BHR & 24 & 28 & 29 & 31 & 33 & 35 \\
\hline & & AHR & 10 & 12 & 13 & 15 & 16 & 18 \\
\hline
\end{tabular}


rolling, the properties such as $\mathrm{AV}, \mathrm{PV}$, and $\mathrm{YP}$ were higher for formulations containing polyAETMAC than those for polyDMAPMA containing formulations for a given concentration. Higher values of rheological parameters may be attributed to the stronger interactive forces between cationic polymer and other anionic additives. On the addition of polyDMAPMA, interaction between clay and polymer chains causes the viscous parameters to increase due to the presence of polar amine moieties present. However, this enhancement in interactive forces among mud additives (mainly clay) and polyAETMAC is greater due to the presence of cationic quaternary amine moieties, which is also supported by the rheological investigations on polymer clay interaction (Fig. 7).

\section{API filtrate}

Hydrostatic pressure of the mud column is kept higher than the pore pressure of formation being drilled, to circumvent the formation fluid from inflowing the wellbore. Due to higher inside pressure, water is infiltrated into the permeable formation and fluid loss takes place which needs to be minimized. Variation of API fluid loss with polymer concentration BHR and AHR is given in Fig. 11. The BHR API filtrate decreased by 15 and $10 \%$ in the presence of polyDMAPMA and polyAETMAC, respectively, at a concentration of $0.625 \mathrm{w} / \mathrm{v} \%$. The reduction in API fluid loss AHR was $~ 20 \%$ for polyDMAPMA and $\sim 13 \%$ for polyAETMAC for the same concentration of the polymers. This suggest that these polymers are effective in reducing API fluid loss even after ageing at $100{ }^{\circ} \mathrm{C}$ and polyDMAPMA being more influential. To investigate the possible reason, textural analysis of filter cakes was done for both polymers and results suggest that polyDMAPMA layer is spread over the solids present in filter cake and reduces the permeability of filter cake resulting in a decrease of API fluid loss. FESEM images of filter cakes formed by drilling formulations containing 0.625 w/v\% of polyDMAPMA and polyAETMAC are shown in Fig. 12 showing a spider web-like network in case of both polymers a characteristic of acrylamide-based polymers (Kelessidis et al. 2013). Filter cake thickness was measured at ten different places, and average cake thickness was found to be $1.2 \mathrm{~mm}$ for polyDMAPMA and 1.07 for polyAETMAC for the formulation with the highest concentration of polymer. The filter cake thickness should be minimum to avoid the problem of pipe stuck during drilling. PolyAETMAC is a forming a thin cake which is desirable for smooth drilling.
Fig. 11 API fluid loss for each formulation before hot rolling (BHR) and after hot rolling (AHR) at $100{ }^{\circ} \mathrm{C}$
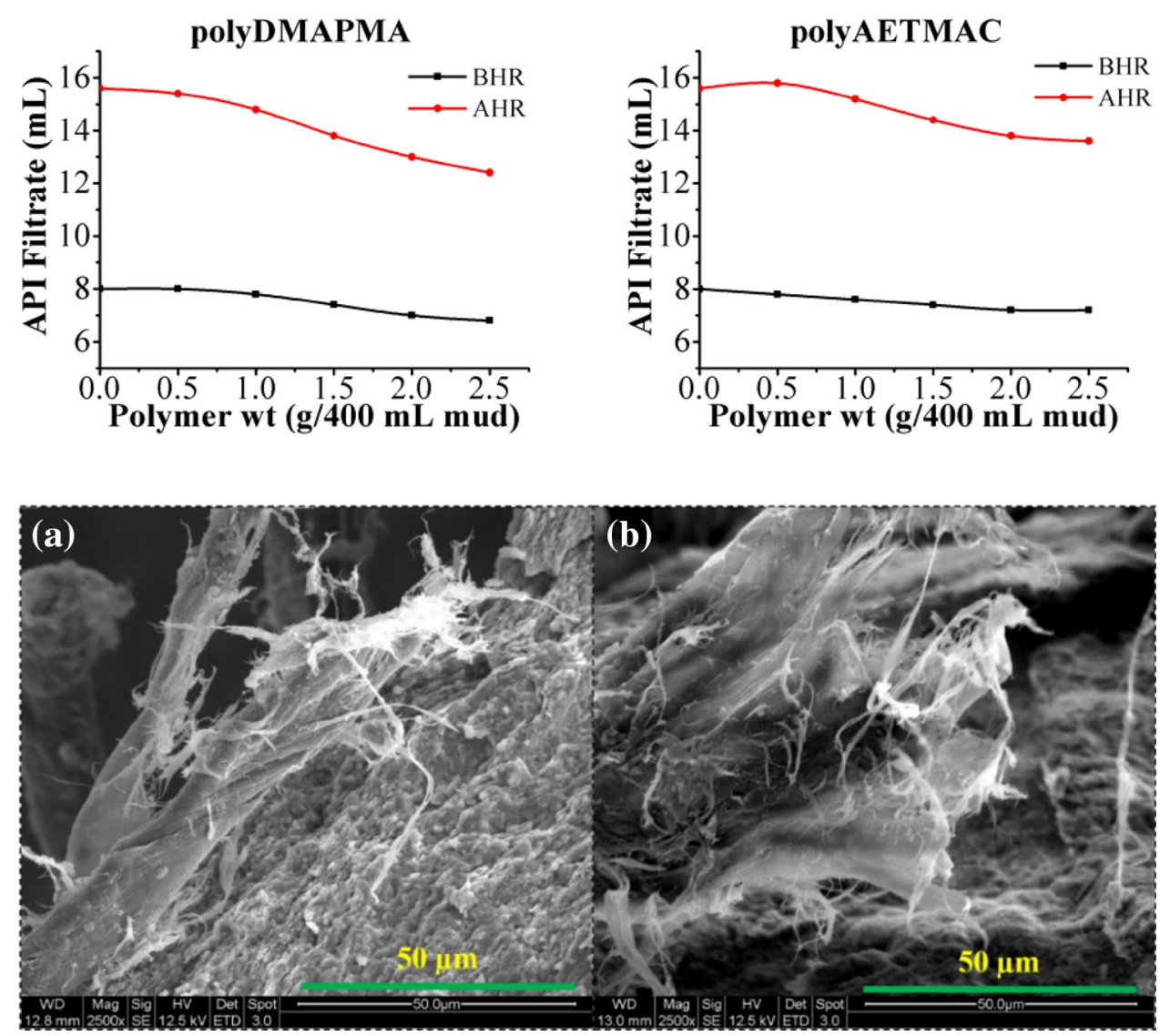

Fig. 12 FESEM images of filter cake formed by fluid containing $0.625 \mathrm{w} / \mathrm{v} \%$ of (a) polyDMAPMA and (b) polyAETMAC 


\section{Hot-rolling dispersion}

During the ageing process, in which drilling fluid sample is hot rolled at a certain temperature for $16 \mathrm{~h}$, shale cuttings were placed in ageing cell along with mud for shale disintegration test. After the hot-rolling process, shale cuttings were sieved out to calculate the recovery $\%$ of the initial amount of shale placed for hot rolling. Since water-sensitive shale starts disintegrating due to interaction with water from WBM, fraction of shale cuttings disintegrated during the hot-rolling process is calculated and remaining amount is called shale recovery. Figure 13 shows the shale recovery of various formulations containing varying amount of polymeric shale stabilizers. Shale recovery percentage for base mud was found to be $92.30 \pm 0.08$ which increased to $98.02 \pm 0.11$ for polyDMAPMA and $98.67 \pm 0.21$ for polyAETMAC for a dosage of $2.5 \mathrm{~g}$ polymer per $400 \mathrm{~mL}$ of base mud in both cases. The shale recovery for polyAETMACbased formulations is higher than that of polyDMAPMAbased muds. It means that cationic polymer has ability to strongly control the shale disintegration. It may be attributed to the fact that cationic sites present in polyAETMAC were adsorbed on the surface of shale with stronger force due to the higher charge density of cation. This causes shale particles to be held strongly with each other during hot rolling, and thus, shale cuttings remain intact.

\section{Linear swell meter test}

FANN linear swell meter (LSM) test is a method of quantitative assessment of shale hydration in terms of shale swelling with respect to time. In this instrument, the compacted shale sample is placed in the mesh under the probe that helps to measure the swelling percentage over the time (Savari et al. 2013). Figure 14 shows the graphs between swelling percentages of shale with different solutions vs. time (h). Swelling percentage value for shale pellet in water was 33\%

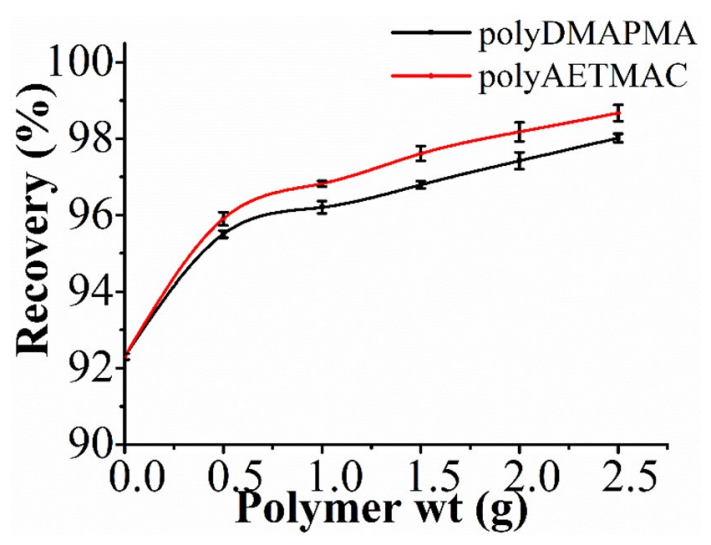

Fig. 13 Shale recovery after hot rolling for $16 \mathrm{~h}$ at $100{ }^{\circ} \mathrm{C}$

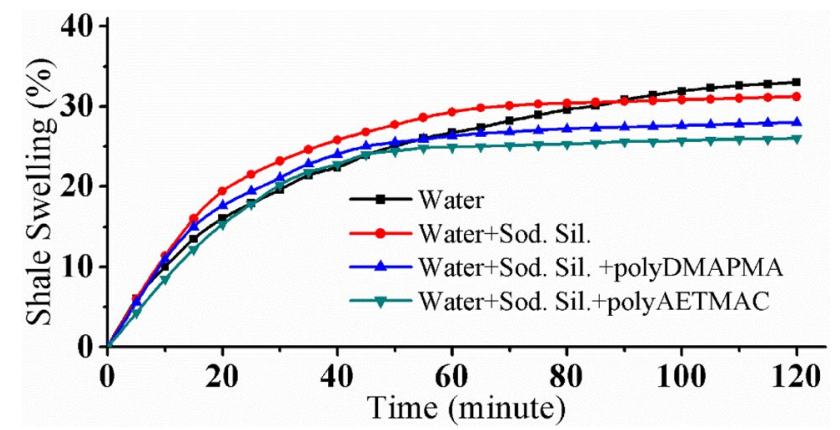

Fig. 14 LSM of shale sample with water, sodium silicate $(8 \%)$ in water, sodium silicate (8\%) and polyDMAPMA $(0.50 \%)$ in water and sodium silicate $(8 \%)$ and polyAETMAC $(0.50 \%)$ in water

which reduced to $31 \%$ in the presence of $8 \%$ sodium silicate in water. The polymeric additives for shale stabilization showed further reduction in shale swelling when added to water and sodium-silicate solution. PolyDMAPMA and polyAETMAC reduced the shale swelling to only $28 \%$ and $26 \%$, respectively, when $0.50 \mathrm{w} / \mathrm{v} \%$ of each was added into sodium-silicate aqueous solution. From the results of LSM values, it was found that there is significant improvement in shale stabilization through decrease in shale hydration. It was also found that cationic polymer polyAETMAC is more effective in swelling inhibition.

\section{Capillary suction time}

An effective shale-stabilizing additive will prevent the water absorption and swelling of the shale which in turn will result in more free water and a permeable filter cake leading to a smaller CST time interval. Table 5 shows the CST values of four different formulations studies on CST apparatus. Base mud when diluted to five times give a CST value of $340 \mathrm{~s}$ with $4.0 \mathrm{w} / \mathrm{v} \%$ shale powder. The addition of $5.0 \mathrm{w} / \mathrm{v} \% \mathrm{KCl}$ reduces this value to $307 \mathrm{~s}$ which is comparable to the CST value by the sample containing $0.5 \mathrm{w} / \mathrm{v} \%$ polyDMAPMA. However, the CST value obtained using $0.5 \mathrm{w} / \mathrm{v} \%$ of polyAETMAC was $291 \mathrm{~s}$. This suggested that polyAETMAC is more effective in stabilizing the shale sample. This may be due to the strong interaction between cationic sites of polymer with anionic sites present in clay minerals of shale.

Table 5 Capillary suction time of $\mathrm{KCl}$ and polymer additives

\begin{tabular}{ll}
\hline Sample & CST $(\mathrm{s})$ \\
\hline Base mud & $339.67 \pm 7.09$ \\
Base Mud $+5.0 \mathrm{w} / \mathrm{v} \% \mathrm{KCl}$ & $307.00 \pm 5.56$ \\
Base Mud $+0.5 \mathrm{w} / \mathrm{v} \%$ polyDMAPMA & $302.67 \pm 4.16$ \\
Base Mud $+0.5 \mathrm{w} / \mathrm{v} \%$ polyAETMAC & $291.33 \pm 4.93$ \\
\hline
\end{tabular}




\section{Conclusion}

The study revealed that polymers based on amine pendant functionality efficiently stabilize the shale formation when present as a drilling fluid additive. Importantly, charged amine-based low-molecular-weight polymers are more effective in shale stabilization compared to the neutral amine functionality-based polymers. Charged amine-based polymer, i.e., polyAETMAC, is also more effective in enhancing the rheological parameters such as apparent viscosity, yield point etc. as indicated by the mud testing of various drilling formulations using FANN VG meter. This may be attributed to the fact that the stronger interaction between cationic sites in polyAETMAC and sodium montmorillonite platelets with negative sites has increased the rheological properties of clay dispersion. API filtration loss was reduced to some extent with the addition of both types of polymers and more prominently in case of polyDMAPMA due to the formation of a spider web-like structure by polymer on filter cake. Shale stabilization effect of additives was evident by the increase in shale recovery performance test. Overall, these polymers can be potential shale-stabilizing additives for drilling with water-based mud. Among the two polymers studied, the charged amine polymer showed better characteristics of shale stabilizer through shale disintegration test, LSM and CST test results.

Acknowledgements We gratefully acknowledge the Department of Science and Technology, India for the financial support for project (Grant: SB/S3/CE/067/2015). Oil and Natural Gas Corporation, India is also acknowledged for providing testing facilities, shale sample, and PAC. We also acknowledge Materials Research Center, MNIT, Jaipur for NMR analysis. We also extend our gratitude towards Ms Yashfeen Khan and her supervisor Prof. Anees Ahmad, Department of Chemistry, Aligarh Muslim University, Aligarh for TGA analysis. The authors declare no competing financial interests.

Open Access This article is distributed under the terms of the Creative Commons Attribution 4.0 International License (http://creativeco mmons.org/licenses/by/4.0/), which permits unrestricted use, distribution, and reproduction in any medium, provided you give appropriate credit to the original author(s) and the source, provide a link to the Creative Commons license, and indicate if changes were made.

\section{References}

Aftab A, Ismail AR, Ibupoto ZH (2017) Enhancing the rheological properties and shale inhibition behavior of water-based mud using nanosilica, multi-walled carbon nanotube, and graphene nanoplatelet. Egypt J Pet 26:291-299. https://doi.org/10.1016/j. ejpe.2016.05.004

Beg M, Sharma S, Ojha U (2018) Effect of cationic copolyelectrolyte additives on drilling fluids for shales. J Pet Sci Eng 161:506514. https://doi.org/10.1016/j.petrol.2017.12.009
Caenn R, Darley HCH, Gray GR (2011) Composition and properties of drilling and completion fluids. Gulf Professional Publishing, Houston

Cao J, Meng L, Yang Y et al (2017) Novel acrylamide/2-acrylamide2-methylpropanesulfonic acid/4-vinylpyridine terpolymer as an anti-calcium contamination fluid-loss additive for water-based drilling fluids. Energy Fuels 31:11963-11970. https://doi. org/10.1021/acs.energyfuels.7b02354

Deville JP, Fritz B, Jarrett M (2011) Development of water-based drilling fluids customized for shale reservoirs. SPE Drill Complet 26:484-491

Feng D, Li X, Wang X et al (2018) Water adsorption and its impact on the pore structure characteristics of shale clay. Appl Clay Sci 155:126-138. https://doi.org/10.1016/j.clay.2018.01.017

Fink JK (2012) Petroleum engineer's guide to oil field chemicals and fluids. Gulf Professional Publishing, Houston

Gholizadeh-Doonechaly N, Tahmasbi K, Davani E (2009) Development of high-performance water-based mud formulation based on amine derivatives. In: SPE international symposium on oilfield chemistry. The Woodlands, pp 1-8

Gomez S, Patel A (2013) Shale Inhibition: what works? In: SPE international symposium on oilfield chemistry. The Woodlands, pp 1-11

Gueciouer A, Benmounah A, Sekkiou H et al (2017) Valorization of $\mathrm{KCl} / \mathrm{PHPA}$ system of water-based drilling fluid in presence of reactive clay: application on Algerian field. Appl Clay Sci 146:291-296. https://doi.org/10.1016/j.clay.2017.06.007

Guo J, Yan J, Fan W, Zhang H (2006) Applications of strongly inhibitive silicate-based drilling fluids in troublesome shale formations in Sudan. J Pet Sci Eng 50:195-203. https://doi.org/10.1016/j. petrol.2005.12.006

Jain R, Paswan BK, Mahto TK, Mahto V (2017) Study the effect of synthesized graft copolymer on the inhibitive water based drilling fluid system. Egypt J Pet 26:875-883. https://doi.org/10.1016/j. ejpe.2015.03.016

Kelessidis VC, Zografou M, Chatzistamou V (2013) Optimization of drilling fluid rheological and fluid loss properties utilizing PHPA polymer. In: SPE middle east oil and gas show and conference. Manama, Bahrain, pp 1-9

Khodja M, Canselier JP, Bergaya F et al (2010) Shale problems and water-based drilling fluid optimisation in the Hassi Messaoud Algerian oil field. Appl Clay Sci 49:383-393. https://doi. org/10.1016/j.clay.2010.06.008

Liu F, Darjani S, Akhmetkhanova N et al (2017) Mixture effect on the dilatation rheology of Asphaltenes-Laden interfaces. Langmuir 33:1927-1942. https://doi.org/10.1021/acs.langmuir.6b03958

Mahto V, Sharma VP (2004) Rheological study of a water based oil well drilling fluid. J Pet Sci Eng 45:123-128. https://doi. org/10.1016/j.petrol.2004.03.008

Mahto V, Srikanth P, Krishna BV (2013) Development of non-damaging and inhibitive water based oil well drilling fluids. Pet Sci Technol 31:721-726. https://doi.org/10.1080/10916466.2010.531353 doi

Mozaffari S, Tchoukov P, Atias J et al (2015) Effect of asphaltene aggregation on rheological properties of diluted Athabasca Bitumen. Energy Fuels 29:5595-5599. https://doi.org/10.1021/acs. energyfuels.5b00918

Mozaffari S, Tchoukov P, Mozaffari A et al (2016) Capillary driven flow in nanochannels - application to heavy oil rheology studies. Colloids Surf A Physicochem Eng Asp 513:178-187. https://doi. org/10.1016/j.colsurfa.2016.10.038

Mozaffari S, Li W, Thompson C et al (2017) Colloidal nanoparticle size control: experimental and kinetic modeling investigation of the ligand-metal binding role in controlling the nucleation and growth 
kinetics. Nanoscale 9:13772-13785. https://doi.org/10.1039/ C7NR04101B

O'Brien DE, Chenevert ME (1973) Stabilizing sensitive shales with inhibited, potassium-based drilling fluids. J Pet Technol 10891100. https://doi.org/10.2118/4232-PA

Patel AD (2009) Design and development of quaternary amine compounds: shale inhibition with improved environmental profile. In: SPE international symposium on oilfield chemistry. The Woodlands, Texas, USA

Patel A, Stamatakis E, Young S, Friedheim J (2007) Advances in inhibitive water-based drilling fluids-can they replace oil-based muds? In: SPE international symposium on oilfield chemistry

Qu Y, Lai X, Zou L, Su Y (2009) Polyoxyalkyleneamine as shale inhibitor in water-based drilling fluids. Appl Clay Sci 44:265-268. https://doi.org/10.1016/j.clay.2009.03.003
Saboori R, Sabbaghi S, Kalantariasl A, Mowla D (2018) Improvement in filtration properties of water-based drilling fluid by nanocarboxymethyl cellulose/polystyrene core-shell nanocomposite. J Pet Explor Prod Technol 8:445-454. https://doi.org/10.1007/s1320 2-018-0432-9

Savari S, Kumar A, Whitfill DL et al (2013) Engineered LCM design yields novel activating material for potential application in severe lost circulation scenarios. In: North Africa technical conference \& exhibition. Cairo, Egypt, pp 1-10

van Oort E, Ripley D, Ward I et al (1996) Silicate-based drilling fluids: competent, cost-effective and benign solutions to wellbore stability problems. In: IADC/SPE drilling conference. New Orleans, pp 189-203

\section{Affiliations}

\section{Mukarram Beg $^{1} \cdot$ Priyanka Singh $^{1} \cdot$ Shivanjali Sharma ${ }^{1}\left[\right.$. Umaprasana Ojha ${ }^{2}$}

1 Department of Petroleum Engineering, Rajiv Gandhi Institute of Petroleum Technology, Jais, Amethi, Uttar Pradesh 229304, India
Department of Chemistry, Rajiv Gandhi Institute of Petroleum Technology, Jais, Amethi, Uttar Pradesh 229304, India 